DE DE GRUYTER

OPEN

DOI: 10.2478/aa-2014-0008

\title{
The Individual and the Nation in Ngũgĩ wa Thiong'o's Early Writing
}

\section{Simona Hevešiová}

Simona Hevešiová is an assistant professor at the Department of English and American Studies of the Constantine the Philosopher University in Nitra, Slovakia, where she lectures and teaches courses on British and postcolonial literature. Her research focuses primarily on the area of postcolonial studies and postcolonial writing. Dr. Hevešiová is the co-author of the following monographs: Cultural Encounters in Contemporary Literature; Multicultural Awareness: Reading Ethnic Writing and Literature and Culture.

\begin{abstract}
In its essence, postcolonial literature evolved as an opposition to colonial discourse and ideological representation of the colonized subject inherent in colonial narratives. Springing out of the need to reconceptualize and reconstitute their communities, postcolonial writers often addressed the pressing historical and political issues of that time in their writing. In its early stages, postcolonial literature was therefore often marked by a strong sense of nationalism, interweaving fictional stories with the public narrative of pre-independence ideology. The paper seeks to explore the border between the public and the private in the early novels of the Kenyan writer Ngũgĩ wa Thiong'o. Just as his contemporaries in other colonized countries, Ngũgĩ wa Thiong'o tends to utilize literature as a powerful tool for raising national awareness. The pre-independence period, in which Ngũgi's novels are set, is marked by a certain degree of romanticism and idealism, yet there is also an underlying sense of doom. Drawing on the cultural roots and mythology of his community, the writer steers his narrative in the direction of a larger, public discourse, suggesting that "the individual finds the fullest development of his personality when he is working in and for the community as a whole". Therefore, the public/private dichotomy stands at the very centre of his writing, proving the rootedness of the individual in the public space.
\end{abstract}

In its essence, postcolonial literature has evolved as a reaction to the historical and political implications of the colonizer-colonized relationship and has, therefore, always been tied to a larger, public discourse. The writings, especially in the early stages of postcolonial literature, thus bear the imprint of the political development in the colonies since local writers often addressed the pressing historical and political issues of that time. In the pre-independence period, literature became a vital tool of political resistance, conjuring images of unified communities and shared cultural heritage intended to raise national awareness and mobilize communities. This paper seeks to explore early nationalist writing in the context of African literature, focusing on the prominent Kenyan author Ngũgĩ wa Thiong'o, who interweaves fictional stories with the public narrative of pre-independence ideology, and to demonstrate how drawing on the cultural roots and founding myths the writer steers his narrative in the direction of a political discourse.

In the context of African literature, from the 1930s onwards writers' commitment to social and political issues was regarded by many intellectuals as a moral duty. In the words of Chinua Achebe, "[...] an African creative writer who tries to avoid the big social and political 
issues of contemporary Africa will end up being completely irrelevant - like that absurd man in the proverb who leaves his burning house to pursue a rat fleeing from the flames" (Achebe, 1968). The pre-independence period in particular called for activism and involvement, and many African writers used literature as "a weapon of political liberation", enlisting their work in the anti-colonialist cause (Boehmer, 2005, p. 175). There was an agreement that literature should be representative of the "moving spirit in the nationalist struggle" (ibid.) and that it should facilitate much needed social transformation.

Moreover, rather than seeing national identity as something fixed and unchanging, postcolonial writers recognized it as a "historical construct, constituted in particular by the [...] narratives which particular communities tell themselves about who and what they are" (Williams, 1999, p. 18). In this respect, the narratives themselves contributed to the construction of national identity, thus validating literature's role in nationalistic causes. In an attempt to grasp the national self-image, the emphasis on shared cultural heritage, collective memory, founding myths and symbolism sought to contribute to the cultural revival of the colonized communities. Writers were seen as "beacons, soothsayers, and seers of political movements" and therefore it was "the writer's role to reinterpret the world, to grasp the initiative in cultural self-definition" (Boehmer, 2005, p. 176). It was through literature that traditional and communal relationships were recreated and European projections of colonized subjects were antagonized.

The Kenyan writer Ngũgĩ wa Thiong'o was a particularly passionate activist in the area of national redefinition and regeneration. In his book of essays Writers in Politics, Ngũgĩ comments on the connection between literature and politics as follows: "A writer's subject matter is history: i.e. the process of man acting on nature and changing it and in so doing acting on and changing himself. The entire changing relations of production and hence the changing power relations consequent on mutable modes of production is a whole territory of a writer's literary concern. Politics is hence part and parcel of this literary territory" (Thiong'o, 1981, p. 72). Literature is then seen not only as a medium which reflects social reality but rather as a creative process that is conditioned by historical social forces and pressures. "[I]t cannot elect to stand above or transcend economic, politics, class, race or what Achebe calls 'the burning issue of the day' because those very burning issues with which it deals take place within an economic, political, class and race context" (ibid., p. 6).

Ngũgĩ's early novels - Weep not, child (1964), The River Between (1965) and A Grain of Wheat (1967) - are all marked by his social campaigning and zealous activism as they portray the disruptive practices of European colonizers in local communities. The novels are set during different periods of Kenyan history, yet they all articulate heavy criticism of the British colonial system and its destructive impact by depicting communities on the verge of disintegration and collapse. In this sense, there is a strong echo of Achebe's Things Fall Apart in all three texts since the need for a stable centre which holds the family unit together, and thus the community and the country respectively, is reiterated repeatedly. Ngũgĩ's texts can be characterized as politically committed literature which utilizes the form of the novel as a medium of anticolonial argument. Moreover, as will be demonstrated in the following paragraphs, his novels also function as national allegories in which the individual characters and events operate in a larger context.

Ngũgĩ's debut novel Weep not, Child as well as his third published book A Grain of Wheat are both set during the Kenyan (or Mau Mau) Emergency (1952-1960), a turbulent period preceding the declaration of Kenyan independence in 1963. The River Between, on the other hand, unfolds during an earlier stage of British colonization of Kenya, soon after the arrival of the colonizers, and maps the gradual transformation of the community under the influence of British missionaries. While the first two novels are focused on events in small communities affected by the presence of European colonizers, the third novel, also set in a small Kenyan 
village, is explicitly political since it traces a detailed account of the Kenyan journey to independence, drawing on historical facts and crucial events as well as introducing significant historical personalities. At first sight, the novels are set in small rural communities, yet the seemingly small-scale incidents are reflective of larger events in the country and thus parallel the national struggle for identity. In fact, it is impossible not to read Ngũgĩ's texts against the backdrop of socio-political transformations in Kenya since they present vital parts of the narratives.

Furthermore, the author problematizes the concept of historical meaning "by blurring boundaries between national and individual events, between factual history and fiction, thus throwing into question the process by which subjects position themselves in history and the ways they might conceive and tell the story" (Kessler, 1994, p. 76). The novels not only document the history of the country, they also provide the author with the space to rewrite the history from the perspective of the formerly silent colonized subject that was believed to have been deprived of its voice: "Ngugi posits narrative here as an agent of history because it provides the space for challenging our notions of national identities, uses of history, and ways in which they are deployed in power contestation in modern Kenya and Africa in general" (James, 1999, p. 2). His novels thus not only reconstruct the history of the country but also take the liberty to modify and mould the historical narrative in such a way that suits his artistic purposes.

Clearly, Ngũgĩ's early writing ponders the nationalist discourse of the 1960s by attempting to articulate the concepts of individualism and national identity. While the communities depicted in the novels struggle with disintegration and discord, the writer attempts to recreate the spirit of unity by reviving communal history and roots. To a certain extent, Ngũgĩ's first novels are repetitive because they keep recycling the same elements of communal and national history, such as the founding myth, or the creation myth, of the Gikuyu, the prophecies of Mugo wa Kibiro anticipating the arrival of the white man, and the references to "Wachiori, the glorious warrior" and "Kamiri, the powerful magician" (Thiong'o, 1965, p. 3). On one hand, these allusions to the glorious past and the line of great tribal personalities counter the colonialist representation of indigenous communities as ahistorical entities, yet on the other hand, they reinforce the feeling of a shared history which functions as a source of unity and homogeneity. In the words of Waiyaki, the aspiring communal leader in The River Between: "A people's traditions could not be swept away overnight. That way lay disintegration. Such a tribe would have no roots, for a people's roots were in their traditions going back to the past, the very beginning, Gikuyu and Mumbi" (Thiong'o, 1965, p. 141).

While the community is pulled apart in different directions, it is these historical and cultural commonalities that should tie people together. The invocation of the past and tribal myths serves as a balancing counterpoint to the chaotic present and Ngũgĩ "seeks to found a sense of self in a recovery of history, a recuperation of tradition" (James, 1999, p. 46). However, the references to joint heritage and ancestry not only contribute to the strengthening of the communal self but at the same create a sense of rootedness and unity. This is where the anticolonial struggle and resistance is directed from as these ancestral and tribal sources function as a counter-discourse to the rhetoric of the European colonizers and their African converts. For example, the communal affinity to the land is derived from the founding myth of the Gikuyu, so when the British start to occupy the land (like Mr Howlands in Weep not, Child) and impose taxes on it, the recourse to the ancestral myth feeds and justifies the communal anger and need for action.

Aside from the evocation of the communal self, Ngũgĩ also delineates his vision of social and political transformation. In Weep not, Child and The River Between the promise of a better future is tied to the concept of education and advancement which should secure communal harmony and unity. Both Njoroge and Waiyaki reiterate the importance of schooling in the 
process of nation-building; they believe that knowledge "would uplift the tribe" so that "in the end the tribe would be strong enough, wise enough, to chase away the settlers and the missionaries" (Thiong'o, 1965, p. 87). However, Waiyaki's and Njoroge's vision, based on the eclectic combination of European education and tribal customs and wisdom, proved ineffectual as reconciliation and unity were not achieved. A Grain of Wheat, therefore, marks a shift in Ngũgĩ's rhetoric; the anticolonial struggle is embodied by the Mau Mau resistance which pleads sacrifice and violence if necessary. The new strategy is articulated by the resistance fighter Kihika who pays for his ideals with his own life: "A day comes when brother shall give up brother, a mother her son, when you and I have heard the call of a nation in turmoil" (Thiong'o, 1986, p. 15). Waiyaki's and Njoroge's idealism, built on the syncretism of both cultures, is thus supplanted by a more radical approach which claims the lives of people in the name of political commitment.

Since the personal stories of his heroes always unfold upon the background of the country's own struggle for existence, most of the central characters in Ngũgĩ's novels, in fact, assume a symbolical role. Especially in the early novels, their function within the narrative tends to be clearly delineated right from the beginning. His characters seem to be predestined to become the leaders of their communities, either through prophecies of the tribal seers or through a self-imposed sense of duty. In the wake of Ngũgĩ's beliefs, "[i]n the African way, the community serves the individual. And the individual finds the fullest development of his personality when he is working in and for the community as a whole" (Thiong'o quoted in James, 1999, p. 15). In The River Between, Waiyaki assumes the role of saviour which was outlined for him by his ancestral lineage. This role is attributed to him early on in the story when his father Chege introduces him to Mugo's prophecy: "Salvation shall come from the hills. From the blood that flows in me, I say from the same tree, a son shall rise. And his duty shall be to lead and save the people" (Thiong'o, 1965, p. 20).

Due to the prophecy, and a heavy use of foreshadowing (Ngũgĩ's literary trademark), Waiyaki's fate becomes quite predictable as he takes on the role imposed on him. He becomes the embodiment of the anticolonial opposition, an authority that attempts to reconcile the two antagonistic ridges. "The myth helps Ngugi in articulating his theme of public responsibility which is seen as an educated man's burden that Waiyaki must take on" (Ogude, 1999, p. 69). As a result, "Waiyaki has very little personal agency outside that cut out for him in nationalist rhetoric" (ibid.). The same holds true for the representatives of opposing forces - the British colonizers, missionaries and their converts. Joshua (The River Between), one of the first converts to the Christian faith, epitomizes the disruptive power of the European influence and adopts the rhetoric of the colonizer which condemns tribal practices. "In Siriana he found a sanctuary and the white man's power and magic [...] The new faith worked in him till it came to possess him wholly. He renounced his tribe's magic, power and ritual" (Thiongo, 1965, p. 29). His role within the narrative is rather functional and fits into the simplistic polarization of the protagonists; hence, there is not much space for him to develop into a psychologically complex character.

In A Grain of Wheat and Weep not, Child, the character portrayal becomes much more complex as the author attempts to tackle the tension between individualism and collective consciousness. In these two novels, "[p]eople get inserted into historic moments in society which exact certain demands on them as part of the collective or national experience, but they also have specific histories as individuals which have a bearing on how they respond to the demands of history" (Ogude, 1999, p. 73). Mr Howlands, the British landowner who settled in Kenya after the disillusionment and death of his son brought about by the First World War, is a good example of this shift in characterization. His relationship to Kenya is not that of an exploiter (though he owns a considerable amount of land); he regards the country as his home now. Moreover, his hostile relationship to Britain, his homeland, humanizes his portrayal as it 
excludes him from the stereotypical characterization of the colonizers in some other African novels.

In $A$ Grain of Wheat, there are multiple examples of complex psychological characterization, yet the most obvious one is that of Mugo, a solitary villager, returning home from the British detention camps. While his bravery is idealized and praised by the villagers to such an extent that he becomes a legend, the writer uncovers his inner battles created by bad choices he made. Ironically, Mugo is asked to make a speech during the independence celebrations in honour of his friend Kihika, who was killed by the colonial administrators. No one knows that it was actually Mugo who betrayed Kihika - a popular resistance fighter - to the administrators and thus became responsible for his death. It is via the contradiction between the internal and external layers of the story that the author points to the complexities of the position of an individual within a larger social context. In this novel, the characterization moves away from typological limitations and gives way to depth and complexity.

As has been demonstrated, the collective and the individual are strongly interconnected in Ngũgĩ's novels and the theme also interferes with the structural organization of the text. In $A$ Grain of Wheat, for example, the collective self is also manifested in the form of a lyrical, communal narrative voice which permeates through the novel and which, according to John McLeod, "contributes to the construction of a national consciousness" (2000, p. 94). In other words, this communal 'we' unites all the other individual voices in order to create a national orchestra which sings in unison but without repudiating the present diverse elements. This seems to be the message the author attempts to pass to his own people: "Don't go against the people. A man who ignores the voice of his own people comes to no good end" (Thiong'o, 1986, p. 226).

Moreover, the tension between the individual and the collective is explicitly voiced by the mythic resistance fighter Kihika in A Grain of Wheat. By advocating collective action over individual attempts to struggle against the colonial presence, he tries to raise people's awareness to unite themselves against the British. Even though it is an individual who stands at the core of this national revival and Ngữgi "recognizes the necessity for figures around which collective action can be instigated and organized" (McLeod, 2000, p. 96), he "remains suspicious of the cult of personality that is often created in their wake" (ibid). Therefore, despite the interrelated personal narratives which build up the story of the newly independent Kenya, it is always the unnamed collective narrator who unites these stories and preaches the importance of togetherness.

To conclude, while the early novels of Ngữgi wa Thiong'o function as mediums of a particular socio-political discourse and are, to a certain extent, somewhat schematic, the political aspects of the narrative do not reduce the texts to mere tools of propaganda. The relation between fiction and history proves to be much more complicated than that, since "[i]n the very process of articulating a people's collective consciousness, the writer is led into active political struggles" (Thiong'o, 1981, p. 73). Ngữgi's early work demonstrates that literature should rather be seen as part of a larger historiography because it reflects the complexity of the historical experience and clarifies the ambiguities of the moment. Moreover, the narratives provide "space within which an historical meaning can be contested" and thus become vital tools for "ordering and shaping history" (Ogude, 1999, p. 153). The African writer, then, positions himself as part of the history-making process that tries to redefine the historical account of the continent and find one's place within it (Ogude, 1999, p. 155). 


\section{Works cited:}

Achebe, Chinua. 1968. The Duty and Involvement of the African Writer. Available at:

$<$ http://www.blackpast.org/1968-chinua-achebe-duty-and-involvement-african-writer $>$

Boehmer, Elleke. 2005. Colonial and Postcolonial Literature. Migrant Metaphors. Oxford:

Oxford University Press.

Kessler, Kathy. 1994. Rewriting History in Fiction: Elements of Postmodernism in Ngugi wa Thiong'o's Later Novels. In: Ariel. A Review of International English Literature. 1994, 25:2, pp. 75-90.

McLeod, John. 2000. Beginning Postcolonialism. Manchester/New York: Manchester University Press.

Ogude, James. 1999. Ngugi's Novels and African History. Narrating the Nation. London: Pluto Press.

Thiong'o, Ngũgĩ wa. 1986. A Grain of Wheat. Johannesburg: Heinemann.

Thiong'o, Ngũgĩ wa. 1965. The River Between. Johannesburg: Heinemann.

Thiong'o, Ngũgĩ wa. 1966. Weep not, Child. London: Heinemann.

Thiong'o, Ngũgĩ wa. 1981. Writers in Politics. London: Heinemann.

Williams, Patrick. 1999. Ngugi wa Thiong'o. Contemporary World Writers. Manchester: Manchester University Press.

Simona Hevešiová, PhD.

Department of English and American Studies

Faculty of Arts

Constantine the Philosopher University in Nitra

Slovakia

shevesiova@ukf.sk

This paper is part of the research project KEGA 039UKF-4/2012 Vyučovanie súčasných anglofónnych literatúr ako prostriedok posilňovania kreatívneho a kritického myslenia. 